\title{
Regarding the United States' Currency Strategies and Their Effect on the Chinese Economy
}

\author{
Guanghua Chen, Dan Zhao, and Junyu Tang
}

\begin{abstract}
The international reserve-currency status of the US dollar and the loose monetary policies of the United States inevitably entrap the US government into the Triffin Dilemma. Under the pressure caused by the dilemma, the US government releases so much liquidity that results in a greatly serious damage to the faith of the US dollar and the real economy of the United States. In order to gain the advantage in the new round of economic competition, the United States will not hesitate to compel the RMB appreciation which is regarded as the breakthrough point for the purposes of promoting real economy, increasing export and maintaining the international reserve-currency status of the US dollar and the international leadership of the United States. By analyzing the implementation process and path of the US currency strategy, this paper goes deeply into the procedure and technique of the US currency strategy against China, and concludes that the US monetary policy serves the following two purposes: the first is to reduce and eliminate the pressure of US government's periodical debt repayment on a global scale as much as possible, the second is to utilize the US dollars to maintain and consolidate its competitiveness, initiative and power of control over the global wealth and resource allocation by the comprehensive application of political strategy, military strategy and cultural strategy. Under such influence, some Chinese economic policies in the past ten years are incontrollable or invalid; the "New Normal" of Chinese economy emerges. In order to ensure the sustainable economic development and go over the difficulties of the so called "Three-phase Superposition". It may be a wise choice for the Chinese government to focus on the core national interests and adjust well the relationship with the United States aiming to the strategic cooperation and competition in politics and economy, which is also the essential condition for China to better make the monetary policy more effective.
\end{abstract}

Index Terms-Monetary policy, regulation, financial crisis.

\section{INTRODUCTION}

Throughout the deficit policies last few years before 2013, huge sums of foreign debt have become a serious liability that threatens the global status and economic development of the United States. "The rapid growth of international reserves-a development concentrated in the emerging markets-remains a puzzle." [1] Considerable sums of foreign debt are not merely a complicated financial problem-they even have an influence on the United States' political stability and economic safety, as well as causing diplomatic conflict and

Manuscript received July 30, 2015; revised December 28, 2015. This work was supported by both "China National Planning Office of Philosophy and Social Science "under "National Social Science Fund Project "Grant 11BFX028 and in part by "Tianjin Municipality Universities Training Plan for Discipline Leading Talent” (Dec.2012-Nov.2015).

The authors are with Tianjin University of Finance and Economics Law School, 300222, Tianjin, China (e-mail: sunfighter@126.com, placebo0719@126.com,junyuaa@126.com). military opposition. The United States (who, in the few years since 2009, has been facing the Triffin dilemma) must depreciate the value of the US dollar, implement soft currency policies, restrict imports and reduce trade deficits in order to force the value of the Chinese Yuan to increase. In causing the Chinese Yuan to increase, the United States will spur an increase in the value of the currencies of other economic bodies in East Asia (such as Singapore, Taiwan, Japan and South Korea), which will in turn cause an increase in exports.

Issues such as how to resolve the problems caused by the Triffin dilemma, how to ensure that the United States is a main player in the next round of economic competition, and how to maintain the US dollar's status as an international reserve currency (as well as the United States' status as a global leader) have even been incorporated into the graduation ceremony of the United States Military Academy at West Point. During the graduation ceremony for the Class of 2015 at the United States Military Academy, the Chairman of the Joint Chiefs of Staff, General Martin Dempsey, gave a speech and handed out signed dollar bills. From the perspective of the United States' currency policies toward China (as opposed to a currency war), one can better understand the US federal government's attitude towards the financial crisis, and can even uncover the financial crisis' true nature.

\section{THE IMPLEMENTATION AND DiRECTION OF THE UNITED STATES' CURRENCY STRATEGIES}

From the sole perspective of a currency war between the United States and China, the United States federal government is carefully manipulating the financial market in order to deliberately create a real estate bubble that will reabsorb US dollars abroad as they are reinvested in domestic real estate. The federal government will then choose an appropriate juncture to burst the real estate bubble and dispose of the US dollars that were absorbed by it. By emulating a financial crisis, the US federal government can trigger the devaluation of the US dollar and dispose of any US dollars that were not absorbed by the real estate bubble. These US dollars are largely situated in the foreign reserves of other nations. In addition to this, the federal government will adopt political, economic and diplomatic tactics in order to trigger an increase in the value of the currency of specific nations - in particular, of nations that have large reserves of US currency. China has already become the nation with the largest reserve of US currency in the world, and as such will inevitably be the United States' first target. Some Americans are not willing to witness China rise to power; forcing an increase in the value of the Chinese Yuan is an effective 
means of attacking China's exports and reducing the US' trade deficit with China, thus stopping China's growth in its tracks.

The tactics and implementation of currency policies adopted by the United States in regard to China can roughly be summarized as follows.

\section{A. The US Federal Government Has Established the Status of the US Dollar as a Global Reserve Currency}

The US dollar has become a valuable reserve, the main tender for international transactions, as well as the unit of choice for accounts all over the globe. Various nations have increased their reserves of US dollars, thus causing a boom in the demand for US currency.

\section{B. Meanwhile, the United States Has Come Face-to-Face with the So-Called Triffin Dilemma}

In order to preserve the status of the US dollar as a global reserve currency, the government needs to maintain current account surpluses. However, in order to respond to the demand for US currency, the United States is obliged to run current account deficits.

\section{Exchange of US Dollars for Material Assets}

The United States' most direct means of fulfilling the demand on the part of various foreign nations for reserve currency is to export US dollars in exchange for the material assets of trading nations. By exporting US dollars, the United States also indirectly creates the circulation of currency to nations that have a large demand for US dollars. One could even say that all the United States needs to do in order to obtain real material wealth on the global market is to keep printing dollar bills. In the context of this transaction, the United States is an importer of material assets and an exporter of currency. In accordance with the general laws of a transaction, when the United States exchanges US currency for material wealth, the companies that earn US dollars as part of this transaction may then use those US dollars in order to reclaim material assets of the same value. At this stage, the exchange of US currency for material assets still constitutes a regular exchange in which neither party has any remaining debt.

\section{Sale of US Dollars at a High Price}

demand for US currency. As exporting US dollars is a privilege of the US federal government, the US currency market is a seller's market; that is to say, the United States controls the entire supply for the US currency market. The price of the US dollar has become high in comparison to that of other currencies. Meanwhile, the US federal government is exploiting the price of the US dollar in order to extensively expand global trade, using trade deficits as a means of increasing the circulation of US currency, thus feeding the global demand. In order to rapidly increase their reserves of US dollars and maintain the stability of their national economy, China has begun implementing policies pertaining to the unified regulation of foreign currency. According to these regulation policies, any foreign exchange earnings must be converted into Chinese Yuan before being listed in accounts. Indeed, throughout previous transactions with China, the US federal government could have made use of China's foreign exchange regulation policies in order to distribute currency to China, thus watering down China's currency.

This way, the US government is able to circumvent the central bank of China in order to increase the amount of Yuan on the Chinese market, thus creating inflation. As foreign exchange earnings are converted into Chinese Yuan, the weakness of any US dollars that China earns via international trade becomes adopted characteristics of the Chinese Yuan. This ultimately increases the speed of inflation of the Chinese Yuan, damaging its stability and having a negative influence on the living standards of the Chinese people. At this stage in the implementation of their currency policies, the US government has deliberately raised the price of the US dollar in the interests of maximizing the amount of material assets that the dollar can buy. This in turn has increased the number of US dollars being printed, providing the conditions for the subsequent devaluation of the US dollar. This ultimately serves the same purpose and has the same effects as increasing China's inflation: encouraging this transferal and reallocation of material assets. The only difference is that, in adopting this policy, the US government did not use an appropriate amount of inflation as a means of promoting the realization of China's economic objectives.

The demand for a global reserve currency implies a

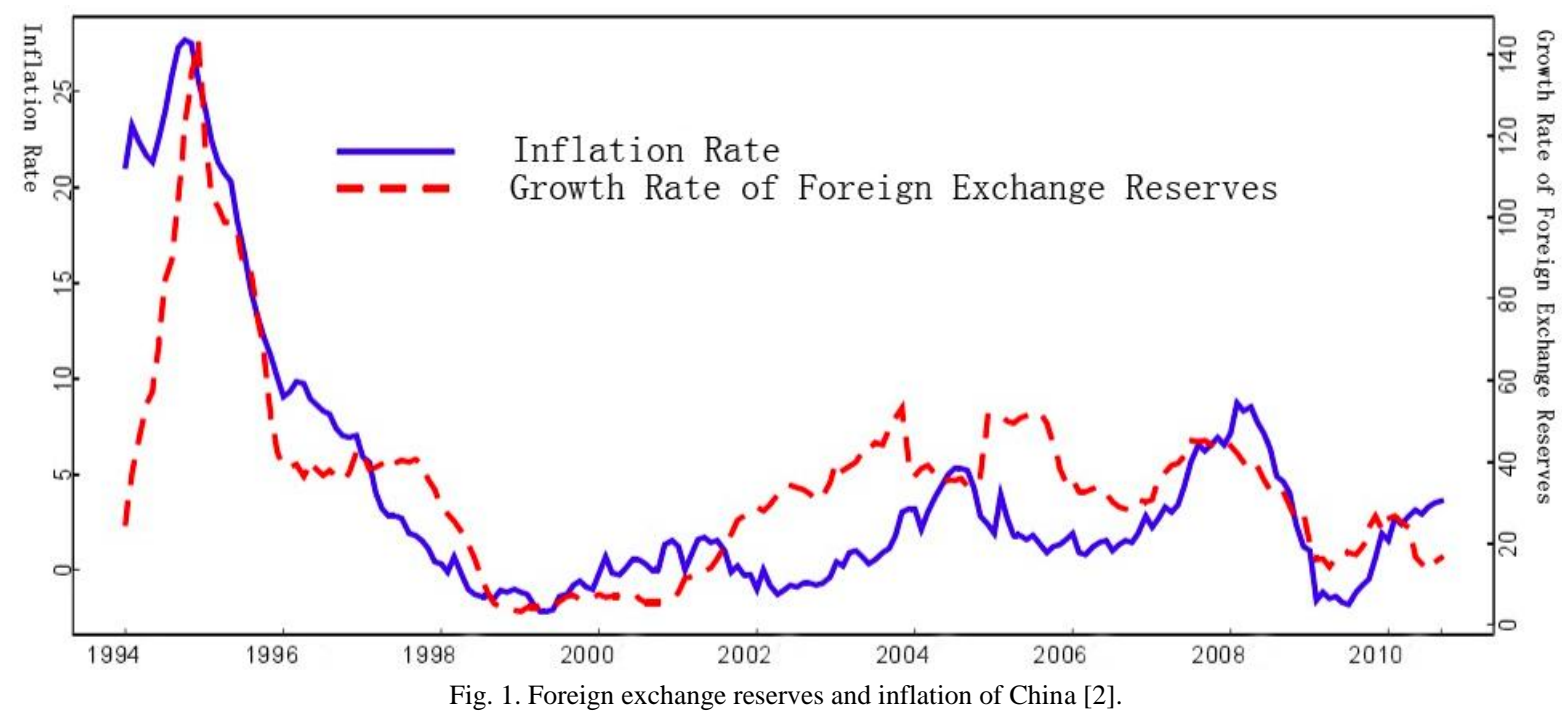




\section{E. Increased Printing of Money}

In order to implement trade deficit policies, the US government requires the support of a massive amount of US currency. This amount of currency is predominantly created by printing money, which is then introduced into circulation via international trade. One could say that nations that issue global reserve currencies can rely purely on printing money in order to engage in international trade. However, what is worth mentioning is that these nations must make sure to maintain the confidence of other nations by not crossing boundaries which put that confidence in jeopardy.

Additionally, through their use of the US dollar, the United States has the potential to introduce the economic risks inherent in the dollar into global economic activity; however, they must avoid inflation risks caused by an excessive accumulation of currency.

\section{F. Implementation of Financial Deficit Policies and Issuance of Debt}

In order to continue implementing their policy whereby currency is exchanged for material assets, the US government must continue to export US currency. Once they have no longer have the means to exploit existent money or create new money, the government's only possibility is to contract foreign loans for the purposes of development - this is a fact that has already been proved by history and the experiences of past generations. The saving habits of the Chinese people not only help the Chinese government to simultaneously exploit and tolerate inflation-they also indirectly help the US government to issue US currency to China. The greatest difference between China and the US in terms of consumption is that Americans borrow money to spend more, whereas Chinese people save money and don't spend. However, the economic realities of modern society are totally different from those of ancient or feudal societies. In past societies, people were saving valuable goods such as gold or silver, so saving was always a positive practice with no inherent risks. However, in modern society, people save currency as opposed to actual material wealth. Cash is not true wealth unless it has already been used in order to purchase real material assets. This is because cash is only paper that represents the trust of the state that issued it - it is not valuable in and of itself. The value of cash entirely depends on the existence and amount of trust it represents. However, as Chinese people have always lived in uncertain environments, they often use savings as means of earning a sense of security and confidence. Almost all Chinese households have savings, and the average amount of these savings is quite substantial. This provides the government with the basic conditions that allow them to issue currency as a means of "fleecing" and taking the material assets of savers. Because Chinese people save money while Americans accumulate material assets, the amount of material assets owned by Chinese people is much smaller than that owned by Americans. The ability of Chinese people to withstand inflation is conspicuously greater than that of Americans. However, should China lose the faith of consumers or enter turmoil, the ability of the Chinese people to endure this turmoil is considerably weaker than that of Americans. This is because, in such a scenario, Americans would be left with their material assets, whereas Chinese people only have cash — which would be rendered useless should the nation's credit begin to crumble.

Throughout the processing of exporting US currency in exchange for material wealth, the US government has made shrewd use of tactics such as issuing debts and contracting foreign loans. Contracting foreign loans does not increase the absolute number of US dollars in circulation, so it does not directly contribute to inflation risks. "Foreign official purchases of dollars have also financed an unprecedented level of external borrowing by the world's biggest economy, the United States." [3] Similarly, at this time the United States will no doubt make efforts to preserve its credit by raising interest on US dollars and by increasing the returns made from US investments. In doing so, the US government can maintain the high price of the US dollar, thus ensuring that the greatest amount of material assets can be acquired for as few dollars as possible. Investors from around the globe are then lured into buying US bonds, causing the US bonds market to continue to flourish and providing the US with ample channels via which they may continue to contract loans. Even more worth mentioning is that many countries have the impression of being held hostage by the US dollar. This is because nations with large reserves of US currency (such as China) wish to get rid of their reserves as they fear the devaluation of the US dollar. Meanwhile, the only means by which nations may get rid of these reserves is to use them for investments - however, there are no available investment options with low risks and high returns. The only possible solution for nations with large reserves of US currency is to keep buying US bonds in the hope that this will reduce the risks and potential losses caused by investing. Currently, China has enormous reserves of US currency; they have no other choice but to purchase US bonds, creating the impression of being held hostage by the US dollar.

Despite trade deficits with other nations, the US has ensured that it continues to gain assets thanks to their use of deficit policies and issuance of debts. As a consequence, Americans benefit from a supply of quality goods at low prices from all over the world. Indeed, following the deduction of various fees, as well as the profits of the manufacturer, goods made in China are sold abroad at much lower prices than domestic prices. This is a direct consequence of the United States' currency strategies.

However, the aforementioned process creates two important burdens for the US government: one, the considerable quantity of US dollars on the market; and two, the considerable quantity of national bonds owned by foreign investors. The natural consequence of this is that all Americans are working to pay off debt; Americans have become the slaves of foreign creditors. Americans are concerned about inflation, and worry that nations with large reserves of US currency will, through their use of those reserves, indirectly affect the development of the US economy, US foreign policy, or the United States' status as a global leader. At this point, the US government must cease the exchange of US currency for material assets; otherwise, the status of the US dollar as a global reserve currency, as well as the status and power of the US government, will suffer. In view of this, the US government will no longer issue debts or implement deficit policies. Instead, it must devote itself to promulgating laws that will eliminate the 
inflation accumulated due to over-printing, as well as the debt caused by issuing bonds. In doing so, the US government may prevent any potential negative effects that debt may have.

G. Emulate a Bubble so as to Reclaim US Dollars in Foreign Reserves, as well as US Dollars on the Chinese Market

As mentioned above, any currency is merely paper that reflects a nation's trustworthiness-and the US dollar is no exception. "International economic integration puts a country's fortunes partly into the hand of others. When integration takes the form of financial interdependence, the potential domestic impact of external events are magnified manifold." [4] If a currency has worth, it is because the nation that issues it uses their credit rating to guarantee the payment. The US dollars circulating abroad are like a huge tiger-they may flow back to the US, influencing the politics, economy, society and culture of the United States. At this time, the United States may create an asset bubble, tempting foreign nations and investors with reserves of US currency to invest in its assets and using the bubble as a means of obtaining more wealth. At an appropriate juncture, the United States may choose to pop the assets bubble, thus destroying any US currency that the bubble absorbed and reducing the pressure of inflation.

\section{H. Provoke a Financial Crisis, Triggering the Devaluation of the US Dollar}

As the amount of US currency that an assets bubble can absorb is limited, there will inevitably still be a large amount of US currency contributing to inflation once the assets bubble has been popped. Meanwhile, the US people will still have to bear the burden created by astronomical sums of foreign debt. Therefore, the US government will need to find a method of disposing of foreign debts, as well as the excess of US currency circulating abroad. The best solution at this stage is to trigger an economic crisis, as it will give the federal government an excuse to decrease the value of the US dollar. The devaluation of the US dollar implies an increase in the cost of products whose price is listed in US currency. As inflation becomes a reality, any US currency in the hands of consumers will be swallowed up by swelling prices. Meanwhile, the devaluation of the US dollar has provided the US government with two perfect gifts. That is to say, the devaluation of US currency held in reserve by nations such as China will directly reduce pressure on the US government to repay debt, allowing the US to continue seizing assets.

\section{UNFAVOURABLE CONSEQUENCES OF THE UNITED STATES FORCING AN INCREASE IN THE VALUE OF THE CHINESE YUAN}

Generally speaking, by exploiting their own status as a nation with large reserves of US currency; by exploiting their political, economic and culture influence in world affairs; and by adopting the aforementioned methods, the US government has been able to reduce the damage caused by an excessive creation of US currency to controllable levels. At this point, they no longer need to continue applying pressure on nations with large reserves of US currency. However, the United
States is continuing to do just that by applying pressure on China and forcing an increase in the value of the Chinese Yuan. The purpose of this pressure is to destroy any US dollars that the China earns through the sale of its labor-intensive goods, whose production consumes large amounts of energy and creates large amounts of pollution. It is commonly known that any US currency earned by China is thanks to its labor-intensive products; these US dollars are a fee that China demands in return for acting as the world's processing plant. The reason why processing plants are moved offshore by developed countries is because the products they produce are not technologically sophisticated and therefore have no competitive power on developed markets. Meanwhile, certain processing plants are moved offshore to China because of China's attractive preferential policies and low labor costs. These products can then earn foreign currency by being exported thanks to incentive policies offered by the Chinese government, which surrender a percentage of profit as a means of stimulating exports. Meanwhile, the low cost of labor means that plant owners gain a large percentage of profits-an alluring prospect for investors and capitalists. Were the salaries of Chinese workers increased to fair and reasonable levels, investors would no longer have any profit to gain. In other words, the main reason why exported goods can bring in foreign revenue is because the cost of Chinese labor has been severely underestimated. The average salary of Chinese workers is only worth half of the US poverty line. Once Chinese reserves of US currency are struck by the catastrophic consequences of the assets bubble and the devaluation of the US dollar, they will then be subject to a second assault as the US government pressures China to increase the value of the Chinese Yuan. As the value of the Yuan increases, the US dollar's value in relation to the Yuan will decrease even more. An increase of $20 \%$ in the value of the Chinese Yuan is equivalent to a decrease of $20 \%$ in the value of the US dollar. China cannot possibly bear the consequences of such an increase. Firstly, such an increase would inflict heavy losses on China's export companies-in particular, export companies that make meagre profits. According to estimations, if the value of the Chinese Yuan were to rise by $20 \%$ in relation to the US dollar, then, based on the volume of trade between China and the US for 2009 [5], the United States would pay 59.28 billion US dollars more to import Chinese products, while China would pay 13.92 billion US dollars less to import American products. American consumers would pay an extra 27.07 billion US dollars for Chinese electronics; 8.18 billion US dollars for furniture, toys, and miscellaneous goods; and 3.13 billion US dollars for light manufactured goods such as shoes and umbrellas. This would considerably reduce the ability of American consumers to buy Chinese products, decreasing the volume of exports and negatively affecting the competitiveness of Chinese goods. It would therefore have catastrophic consequences on Chinese exports and employment; an increase of $1 \%$ in the value of the Chinese Yuan implies an increase of about $1.29 \%$ percentage in export prices. That is why over the past ten years, lots of central banks in LA and Asia have had a regular, and at times large, presence in FX markets. In most instances, this intervention was in one direction only, and coincided with easing of global financial 
conditions that put great appreciation pressures on many EM currencies, including those of L.A. and Asia. While these central banks have stated various motives for their interventions, their nature and timing often suggest an intent or effort to mitigate currency appreciation pressures.

An increase in the value of the Chinese Yuan in relation to the US dollar is tantamount to the US government forcing China to increase the buying power of the Chinese Yuan. It would limit the ability of the Chinese government to increase the number of Chinese Yuan in circulation, while at the same time causing the market demand for Chinese Yuan to soar. It would be equivalent to the Chinese government allowing Chinese people to acquire more products for the same amount of Chinese Yuan, and as such, would inevitably lead to an increase in the price of goods and the market demand, as well as a relative decrease in the supply. An increase in the value of the Yuan would paradoxically decrease or weaken the spending power of any Yuan in the hands of Chinese consumers; therefore, by forcing an increase in the value of the Yuan, the US government is creating a golden opportunity for investors to hedge and sweep up goods on the Chinese market. This will create more inflation for Chinese consumers, as well as triggering an enormous real estate bubble, and would therefore have disastrous consequences for the Chinese economy.

\section{The Current State of the Chinese Economy As It BEARS THE CONSEQUENCES OF US CURRENCY STRATEGIES}

Looking at the trends and objectives of the United States' economic strategies pertaining to China, the pressure of American and European economic bodies on the Chinese Yuan has begun to loosen up now that the US economy is back on the road to steady growth. However, the Chinese economy has already incurred great losses due to opportunities for hot money, as well as the burst of the assets bubble. Reform in the structure of the Chinese economy will not yield conspicuous results in the short term. In the long term, hot money and the hedging of funds in China will pay off, but in the short term, arbitrage will not help investors achieve their objectives. "A large and growing fraction of capital raisings, especially debt issuances, occurs in international markets, but a very small number of firms accounts for the bulk of international capital raisings." [6] The implementation of deregulatory policies in Europe and the United States will create good news for the European and American stock markets; therefore, investors can make profits by retrieving hot money from overseas and buying the dips on domestic markets. The flow of hot money between China and the United States depends on losses and gains. In the long-term, the value of the Chinese Yuan will continue to increase, meaning that the practice of investing hot money in China will continue for a relatively long time. In the short term, however, the investment markets of Europe and the United States may be stimulated through use of deregulation policies, which would create opportunities for investors and in turn cause a lot of hot money to be removed from the Chinese market. In other words, if the long-term benefits of hedging funds in China outweigh the benefits of short-term investment opportunities on European or American markets, much of the hot money currently leaving China may be re-invested in China later on. However, if the American and European economies continue to growth as they are now, then the benefits of domestic investment opportunities will outweigh those of hedging funds in China, and investors will no longer have an incentive to re-invest hot money in the Chinese market. An additional factor is the Chinese government's regulation of the real estate market. China's objective for the reduction of the Chinese real estate bubble should be approximately $35 \%$ of the overall housing price, whereas regulation is currently only achieving an effect of $10-16 \%$. Although China hasn't reached its objective for the regulation of the real estate market, they have still succeeded in decreasing the chance of making profits using hot money by about $10 \%$. Of course, a certain amount of hot money with high risks and high returns is to be expected. In the long-term, the price of Chinese real estate will continue to decrease; however, at the same time, progress in the structural reform of the Chinese economy will make up for the loss of economic power caused by the initial drop in housing prices. As they continue to regulate the price of real estate, the Chinese government must take into account the requirements of economic growth. If the development of other industries is not enough to compensate for any slumps caused by the regulation of real estate, the government's main objective as far as housing prices are concerned should be to seek stability, instead of pursuing the idealistic goal of $35 \%$. In view of this, hot money that is less speculative and more hedge-oriented will stay on the Chinese market until the economies of Europe and the United States recover, and the US dollar becomes strong once again. China then will once again become the world's "processing plant", repeating the model of economic development from the last 20 years.

\section{CONCLUSION}

As far as Europe and the United States are concerned, this will be a new era of growth, while for China, it will be "same old, same old". Whether or not China can avoid trudging down the same old path again will depend on the extent to which it changes the way it develops its economy. Meanwhile, whether or not China can stop being reliant upon American and European markets (as well as the state of development of American and European economies) will depend on its capacity for technological innovation.

The US monetary policy serves the flowing two purposes: the first is to reduce and eliminate the pressure of US government's periodical debt repayment on a global scale as much as possible, the second is to utilize the US dollars to maintain and consolidate its competitiveness, initiative and control power of the global wealth and resource allocation by the comprehensive application of political strategy, military strategy and cultural strategy. Under such influence, some Chinese economic policies in the past ten years have been somehow incontrollable or invalid; the "New Normal" of Chinese economy emerges. In order to ensure the sustainable economic development and go over the difficulties of the so called "Three-phase Superposition". It may be a wise choice for the Chinese government to focus on the core national interests and adjust well the relationship with the United States aiming to the strategic cooperation and competition in politics and economy, which is also the essential condition 
for China to better make the monetary policy more effective.

\section{REFERENCES}

[1] M. Obstfeld, J. Shambaugh, and A. Taylor, "Financial stability, the trilemma, and international reserves," American Economic Journal: Macroeconomics, American Economic Association, vol. 2, no. 2, pp. 57-94, April 2010

[2] N. Li, "Studies on the generating mechanism of inflation and testing for the transition mechanism of inflation in China's economy," Doctoral dissertation, p. 87, Oct. 2011, Jilin University, China.

[3] M. Obstfeld, J. Shambaugh, and A. Taylor, "Financial stability, the trilemma, and international reserves," American Economic Journal: Macroeconomics, American Economic Association, vol. 2, no. 2, pp. 57-94, April 2010

[4] M. Obstfeld, "Financial flows, financial crises, and global imbalances," Journal of International Money and Finance, vol. 31, pp. 469-480, 2012.

[5] According to the statistics by U.S. department of commerce, the bilateral trade volume in 2009 was $\$ 365.98$ billion, among them, the total export from U.S. to China is $\$ 69.58$ billion, and total import from China to U.S. is $\$ 296.4$ billion.

[6] J. C. Gozzi, R. Levine, and S. L. Schmukle, "Patterns of international capital raisings," Journal of International Economics Special Issue: JIE Special Issue on International Macro-Finance, vol. 1, no. 80, pp. 45-57, 2010.

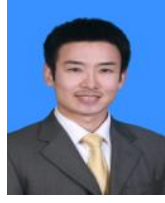

Guanghua Chen was born in August 1962, Hunan Province, China. He received his Ph.D from Renmin University of China Law School in 2006.

$\mathrm{He}$ is an associate dean of law school in Tianjin University of Finance and Economics, a professor, a supervisor of postgraduate. He has published two books: 1.On the effective Essentials of Real Right Change Intellectual Property Press, the 1st edition in July 2008; 2. On the Elements of juristic acts-Based on Empirical Analysis of Real Right Change, Law Press, the 1st edition in September,2009. He also published more than 15 papers at national journals and conferences.

Prof. Chen is a member of the council of China Society of Economic Law, vice secretary-general of Tianjin Commercial Law Society: vice president of Tianjin Economic Law Society; executive director of Tianjin Applied Law Institute; the executive director of Tianjin Legal Education Society.

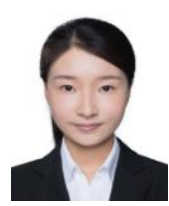

Dan Zhao was born in 1991, Inner Mongolia, China. She is currently a postgraduate student in Tianjin University of Finance and Economics Law School. Her research interest is in the area of international economic law.

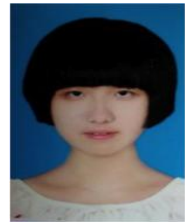

Junyu Tang was born in 1995, Hunan, China. She is currently a senior student in Guangdong University of Finance and Economics Finance Institute, finance major. Her research interest is in the area of Chinese monetary policies. 